DOI https://doi.org/10.32782/2305-9389/2020.22.07

УДК 94 (4)

Бондаренко Олег,

кандидат економічних наук, доцент, викладач Санкт-Петербурзької державної бюджетної професійної загальноосвітньої установи «Російський коледж традииійної культури»

\title{
ВПЛИВ ЛІВОНСЬКОЇ ВІЙНИ НА ВСТАНОВЛЕННЯ САМОДЕРЖАВНОӤ МОНАРХІЇ В МОСКОВСЬКІЙ ДЕРЖАВІ В ДРУГІЙ ПОЛОВИНІ ХVІ СТОЛІТТЯ
}

Мета статті полягає в розкритті деяких аспектів, пов'язаних із проведенням російською владою політики возз 'єднання західноросійських (білоруських) і південноросійських (українських) земель у складі Московської держави. Автор вважає, щзо після розпаду Золотої Орди Московська держава прагнула зайняти місие, щчо звільнило полюса геополітичної сили в прикордонні Східної Свропи та Північно-Західної Азії. Однак на роль гегемона східноєвропейського простору також претендувала польсько-литовська унія.

У дослідженні автором розглядаються основні передумови встановлення самодержавного ладу в Московській державі та спроби з боку иарської влади проводити політикуоб 'єднання східнослов 'янськихземель. Акиентується увага на тому, щзо основні причини, які призвели до Лівонської війни, були зумовлені конфліктом між Московською державою та Великим князівством Литовським через західноросійські й південноросійські території. Уряд Великого князівства Литовського прагнув не допустити посилення Московської держави з ї̈ виходом до Балтійського моря.

Автор вважає, щчо утвердження опричнини було пов 'язане з потрясіннями Російсько-Литовської війни та периими важкими ураженнями царських військ. Це був репресивний захід, спрямований проти служивих людей, які становили основну масу емігрантів, щуо прямувала до Великого князівства Литовського. 3 XV століття й аж до кіния XVII століття відбувалася досить напружена боротьба за представників стану військовиків між польсько-литовською унією та Московською державою.

Оиінка подій XVI століття дає автору змогу зазначити, щзо основним напрямом зовнішньої політики Московської держави був західний, за якого російський уряд прагнув возз'єднати західноросійські землі та проводив експансію в Прибалтичі. Натомість на півдні та сході Москва вела оборонні війни.

Ключові слова: Велике князівство Литовське, Лівонська війна, самодержавство, служиві люди, емігранти.

\section{Bondarenko Oleh. Influence of the Livonian war on the establishment of an autocratic monarchy in the Moscow state in the second half of the XVI century}

The purpose of the article is to reveal some aspects related to the Russian authorities policy of reunification of Western Russian (Belorussian) and southern Russian (Ukrainian) lands into the Moscow state. In the article, the author believes that after the collapse of the Golden Horde, the Moscow state sought to occupy the vacant place of the pole of geopolitical power on the border of Eastern Europe and North-West Asia. However, the Polish-Lithuanian Union also claimed to be the hegemon of the Eastern European space.

In the study, the author examines the main prerequisites for the establishment of an autocratic system in the Moscow state and the attempts made by the tsarist authorities to pursue a policy of unification of the East Slavic lands. It is emphasized that the main reasons that led to the Livonian war were caused by the conflict between the Moscow state and the Grand Duchy of Lithuania over the Western and southern Russian territories. The government of the Grand Duchy sought to prevent the strengthening of the Moscow state with its access to the Baltic sea.

The author believes that the oprichnina's claim was connected with the upheavals of the Russian-Lithuanian war and the first heavy defeats of the tsarist troops. This was a repressive measure directed at the time of its implementation against the families of service people who made up the main mass of emigrants heading to the Grand Duchy of Lithuania. Starting from the XV century and up to the end of the XVII century, there was a very intense struggle for representatives of the service class between the Polish-Lithuanian Union and the Moscow state.

The author's assessment of the events of the XVI century allows him to note that the main direction of the Moscow state's foreign policy was the Western one, where the Russian government sought to reunite the Western Russian lands and carried out expansion in the Baltic States. While in the South and East, Moscow waged defensive wars.

Key words: Grand Duchy of Lithuania, Livonian war, autocracy, service people, emigrants.

Актуальність теми дослідження. Історична наука не має єдності поглядів у такому питанні, як час виникнення самодержавного ладу в Московській державі. Одні дослідники відносять встановлення самодержавної монархії до кінця XV століття, інші - до другої половини XVII століття, деякі вбачають iii початок у XVI столітті. Найбільш спірними й суперечливими судженнями рясніє історіографія епохи Івана Грозного, особливо опричнина. Немає єдиної думки про її становлення й терміни існування, роль і значення в історії російської централізованої держави. Водночас практично не розглядалися такі 
аспекти Лівонської війни, які були пов'язані з проведенням московським урядом політики об'єднання східнослов'янських земель. Саме поразка Московської держави в Лівонській війні та період Смутного часу, що настав згодом, сприяли завершенню процесу формування російського народу. При цьому західноросійські та південноросійські території були виключені із цього процесу. Усі ці події були тісно пов'язані із затвердженням самодержавного ладу в країні.

Мета статті полягає в розкритті деяких аспектів, пов'язаних із проведенням російською владою політики возз'єднання західноросійських (білоруських) і південноросійських (українських) земель у складі Московської держави.

Історіографія проблеми. Період правління Івана Грозного та Лівонська війна завжди притягували увагу дослідників. Вивчення встановлення самодержавного ладу в Московській державі та політики об'єднання східнослов'янських земель здійснювалося багатьма фахівцями з історичної науки, такими як Д.Н. Альшиць, А.Г. Бахтін, Г.В. Вернадський, К. Срусалимський, А.А. Зимін, В.О. Ключевський, С.Ф. Платонов, А. Рамбо, С.М. Соловйов, Р.Г. Скринніков, А.І. Філюшкін, Оскар Халецкі, А.Л. Хорошкевич, Дж. Хоскінг, Т.В. Черникова та інші.

У роки ординського володарювання на території Північно-Східної Русі сталося становлення в ії землях вотчинного устрою, який успадкувала єдина Московська держава кінця XV - початку XVI століття. Основний зміст вотчинного устрою як соціокультурної системи полягає в тому, що монарха варто розглядати у двох аспектах: як політичного главу держави та як верховного власника землі. Таким чином, у Московії погляд на державу як на вотчину затвердився в період удільних князівств і більш загальну форму отримав під впливом ординського ярма [12, с. 46$]$.

Після розпаду Золотої Орди Московська держава мала шанс зайняти місце полюса геополітичної сили, що звільнилося, у пограниччя Східної Європи та Північно-Західної Азії. Проте на роль гегемона східноєвропейського простору також претендувала польсько-литовська унія. 16 січня 1547 p. Великий князь Московський і всієї Русі був урочисто увінчаний титулом царя. Першим російським царем став шістнадцятирічний Іван IV. Після вінчання Івана на царство Глинські захопили необмежену владу у країні [1, с. 33].

Поява на Русі царя випередила встановлення самодержавного ладу. Акт вінчання великого князя на царство не поклав край боярському правлінню. 3 ним покінчило повстання 1547 р. [1, с. 34].

12 квітня 1547 р. вибухнула знаменита московська пожежа. Митрополит і двоє бояр (СкопінШуйський та Челядин) висловили думку, що пожежа підготовлена «певними зловмисниками» за допомогою чаклунства. Вони явно натякали на Глинських. 26 липня 1547 р. бояри скликали загальні збори московського чорного люду. Таким чином, вороги Глинських склали змову, а запеклий народ став їх знаряддям. Упродовж двох днів Москва була під контролем повсталих городян [3, с. 24-26]. Наприкінці 40-x pp. XVI століття за участю митрополита Макарія в оточенні молодого царя опинилися ті особи, яким призначено було в очах сучасників і нащадків символізувати новий уряд - так звану Обрану раду.

Це пов'язано насамперед з А.Ф. Адашевим і Сільвестром [1, с. 34]. Адашев за своїми переконаннями був абсолютно очевидним виразником інтересів людей служивих - широких мас дворянства, основної соціальної опори та озброєної сили централізованої держави. Для досягнення найважливішої мети - збільшення й укріплення дворянського війська - був потрібен фонд видачі «окладу» кожному дворянинові, тобто земля. Через це, а також в інтересах зміцнення свого авторитету як глави держави Іван IV став активним учасником вироблення зовнішньополітичної лінії, спрямованої на розширення держави. Це насамперед сприяло завоюванню Казанського ханства [1, с. 42].

Серед лівонських лицарів існували дві основні партії. Одна 3 них намагалася врятувати країну за допомогою поступок Московській державі, тиск якої став особливо загрозливим за часів Iвана IV. Iнші схилялися до укладення якого-небудь договору з Ягеллонською династією, щоб отримати захист із боку Литви та, відповідно, Польщі [14, с. 205].

У 1554 р. Ландмейстер фон Гален, прибічник російської орієнтації, уклав договір з Іваном Грозним на 15 років. Він пообіцяв не вступати в жодні угоди з Литвою. Хоча через три роки наступник Галена Вільгельм фон Фюрстенберг, який конфліктував з архієпископом Риги, після дипломатичного інциденту з королем Польщі (традиційним покровителем архієпископської єпархії), який зібрав сильне військо в лівонській межі, уклав договір із Сигізмундом II Августом. Цар розглянув це як порушення договору 1554 р. та в 1558 р. вторгся в Лівонію [14, с. 205-206]. Магістр Фюрстенберг, відступивши в 1558 р. до Валки, передав повноваження ландмейстера Тевтонського ордену в Лівонії фелінському командорові Готгарду Кетлеру. Його кандидатуру висунули лівонські дворяни. Ландмейстер відступив до Риги та розпочав там пошуки зарубіжного союзника [18, с. 136-137]. 
Не отримавши підтримки від Швеції, ландмейстер, незважаючи на ворожнечу з ризьким архієпископом, ставлеником Польщі, зв'язався з главою польсько-литовської унії Сигізмундом II Августом для обговорення умов переходу лівонських територій у підданство польського короля. Хоча Рига розглядала ладмейстера та архієпископа як своїх сеньйорів, цієї ініціативи вона не схвалила. Рига бажала отримати статус вільного міста Священної Римської імперії [18, с. 137]. Водночас бранденбурзькі Гогенцоллерни прагнули затвердити свої права на герцогство Пруссію. Для цього необхідно було домовитися з поляками, тому курфюрст Іоахім II почав відповідні переговори. В умовах тривалої Лівонської війни на сході Балтики в 1569 р. поляки визнали наявність у бранденбурзької лінії Гогенцоллернів прав на Пруссію [15, с. 123-124].

У таких умовах частина тевтонської землі знову увійшла до складу однієї з германських держав. Хоча дві великі ії частини залишалися під контролем інших держав. Це були насамперед східні провінції, тобто давні володіння Мечоносців, які, відокремившись від Тевтонського ордену після потрясінь XV століття, стали об'єктом експансії з боку Московської держави [9, с. 192]. Звернення Кетлера до Сигізмунда II Августа в 1559 р. мало подальший розвиток. Ландмейстер готовий був передати всю Лівонію, залишаючи за собою тільки герцогство Курляндське. Відмовитися від «законного» придбання Лівонії Сигізмунд II Август не міг. Понад 100-річна конкуренція з Москвою за західноросійські й південноросійські землі, що з XIII по XIV століття перебували у складі Литви та були частково відібрані Москвою, тільки підштовхувала польсько-литовську сторону до війни у Прибалтиці. Офіційною датою ліквідації Лівонського ордену вважається 5 березня 1562 р. [18, с. 138].

Іван Грозний побоювався не лише «самоправства знаті», а й спроб обмеження єдинодержавності з боку ширших соціальних прошарків, ніж феодальна верхівка. Загрозу самодержавству цар бачив із боку різних сил $[1$, с. 95]. Незгода Івана IV з їх зовнішньополітичним напрямом стала одним із головних приводів для розриву між ним та його радниками. Адашев, Сильвестр і їх прибічники вважали, що варто продовжити активну зовнішню політику на сході та на півдні, а цар спрямував погляд на Лівонію. Той факт, що розбіжність у поглядах призвела до швидкого розриву й ворожнечі царя з колишніми радниками, свідчить про те, що до 1558 р. Іван Грозний як політична сила досить зміцнів для того, щоб зайняти та відстояти самостійну політичну позицію [1, с. 107].

Водночас не зовсім правильно розглядати Адашева як супротивника Лівонської війни. Рішення про напад на Лівонію приймалося Обраною радою в 1556-1558 рр., і Адашев як глава цієї ради не міг його не схвалювати. Більше того, ще до перетворення Кетлера на васала польського короля Обрана рада, припускаючи вірогідність втягування Сигізмунда II Августа в лівонську епопею, вирішила, що Лівонія коштує православних «отчин» московського царя в Литві, тому дала змогу здійснити кардинальний перегляд зовнішньої політики Москви щодо Литви й Польщі. Польсько-литовській стороні запропонували «вічний мир» за відмову від претензій на Лівонію. В обмін Москва обіцяла назавжди відмовитися від своїх вимог на західноросійські (білоруські) та південноросійські (українські) території. Вона готова була створити з Польщею й Литвою міцний військово-політичний союз проти загальних ворогів - Туреччини та Криму, до чого давно вже закликали імператор Священної Римської імперії та Папа Римський [18, с. 138].

Водночас Польща, на відміну від Литви, де думки про такий союз розділилися, боялася Московської держави більше, ніж Туреччини та Криму. «Вічний мир» тільки прискорив би перетворення Московської держави, підкріпленої приморською Лівонією, на однозначного геополітичного лідера Східної Європи. Така перспектива мало що давала полякам, тому Ташкевич не погодився з пропозиціями Адашева, він готовий був вести переговори тільки про перемир'я. За таких умов крах стратегічного російсько-литовського примирення налаштував Адашева на песимістичне ставлення до можливості перемоги в Лівонській війні [18, с. 139].

Війна Московської держави з Лівонським орденом перетворилася на найбільший міжнародний конфлікт, у який були втягнуті низка держав Північної, Центральної та Східної Європи. Цілі цих країн були різними. Скандинавські країни прагнули заволодіти балтійськими портами, забезпечити собі монополію на експлуатацію торгового посередництва в товарообміні між різними регіонами Європи. Інші мотиви мало Велике князівство Литовське. У ньому вирішальну роль відігравала зацікавленість литовських і білоруських феодалів у вільному продажі продуктів своїх маєтків західноєвропейським купцям. Влада Великого князівства Литовського, незважаючи на укладення Віленського договору, повинна була проводити довгу й напружену боротьбу з Ригою за оволодіння гирлом Західної Двіни, що об'єктивно не суперечило прагненню Московської держави контролювати торговий шлях, який проходив на захід узбережжям Фінської затоки. Не стикалися інтереси обох країн і на міжнародному ринку: Московська держава в XVI столітті не експортувала ні хліб, ні лісові товари - головні предмети збуту білоруських, 
литовських і польських феодалів. Проте на відносини обох держав найсильніший відбиток накладав конфлікт через білоруські й українські землі [8, с. 425].

При цьому варто зазначити, що однією із цілей Лівонської війни з боку московського уряду було проведення політики об'єднання східнослов'янських земель. Російські дипломати офіційно заявили, що укладення миру між Москвою та Литвою неможливе, допоки українські та білоруські землі перебувають під владою Ягеллонів. Проте відновлення боротьби між Московською державою та Великим князівством Литовським у перші десятиліття XVI століття відбувалося в іншій обстановці. Тепер панівний клас Великого князівства Литовського (не лише литовські, а й білоруські та українські феодали) не прагнули до возз'єднання білоруських та українських земель із Московською державою, де з кінця $\mathrm{XV}$ століття величезну роль відігравав інститут центральної влади. Українські й білоруські дворяни більшою мірою були пов'язані з польською культурою, ніж із російським самодержавством. Так, Костянтин Острозький тікав із Москви та в 1514 р. завдав російським воєводам жорстокої поразки при Орші [11, с. 191].

Лівонська війна була одним з аспектів політики возз'єднання білоруських та українських земель у складі Московської держави. Тому в 1563 р. російські війська зайняли Полоцьк, що було значним досягненням політики возз'єднання білоруських земель і водночас сильним ударом по позиціях Великого князівства Литовського, адже шлях у Балтійське море по Західній Двіні був перерізаний. У таких умовах на дипломатичних переговорах між Москвою та Литвою в січні 1564 р. цар зажадав не лише Лівонію та Полоцьк, а й усі російські території у Великому князівстві Литовському, а також Львів і Галич [4, с. 252].

Водночас жорсткі методи збирання різних територій були продемонстровані Іваном Грозним на початку 1560-х рр. щодо православного населення західноросійських земель, коли московські війська почали вторгнення в межі Великого князівства Литовського. Відповідно до російської традиції православне населення нібито всюди їх вітало. Проте реальність була набагато складнішою, про що красномовно свідчить оборона головного центру Литовської Русі - Полоцька [18, с. 140].

Опір Полоцька навів царя на думку, що надійніше буде замінити в цьому краї місцевих жителів вихідцями з Московської держави, тому російська влада почала переміщати православних християн із сім'ями в Московську державу, а їх будинки та землі віддавати переселенцям із московських володінь [18, c. 141$]$.

Динаміка зростання міського й особливо столичного населення в Московській державі залежала від політичних чинників більше, ніж сільського. Було би неправильно вважати, що впродовж усієї першої половини XVI століття рух населення здійснювався в одному напрямі - до Москви. Паралельно зі «зведенням» до столиці жителів знову приєднаних міст відбувалося виведення частини московського торгового населення в ці міста. Практика масового виведення населення з провінційних міст до столиці та одиничного виведення зі столиці до провінційних міст перетворилася на систему [16, с. 7].

Початок війни за Лівонію привів до ескалації антипольських та антилитовських настроїв у Московській державі. Падіння Обраної ради було викликане перемогою насамперед ксенофобії щодо Польщі й Литви, які дедалі більше асоціювалися з релігійною толерантністю, тобто віровідступництвом. Страх поступитися владою прибічникам польського короля, виявитися під його владою або поступитися йому спірними землями був характерний для царя та його найближчого оточення. Уже під час Лівонської війни польсько-литовська сторона використала підозрілість царя для дестабілізації вищого управління та прикордонних адміністрацій, розсилаючи листи із закликами перейти на сторону Сигізмунда II Августа [5, с. 5-6].

Водночас не варто розглядати ізольовано від проблеми відносин царя 3 масою служивих людей постійні нападки Івана Грозного на державний устрій Литви й Польщі. Польща, безпосередній сусід Московської держави, була зразком повного безсилля короля перед шляхтою, «країною класичної феодальної розгнузданості». Король на польському престолі був не «помазаник божий», а обирався шляхтою [1, с. 97].

Більшість емігрантів, яких московська дипломатія розглядала як найбільш небезпечних зрадників у роки Лівонської війни, тікали з Москви незабаром після початку бойових дій між Московською державою та польсько-литовською унією. Іван Грозний з 1560-х рр. приділяв багато уваги своїм «зрадникам» в оточенні польсько-литовських монархів, звинувачував їх у зведенні наклепів на себе та країну, у розпалюванні війни, бажанні підпорядкувати Московську державу Речі Посполитій. Поряд із Московською державою виник серйозний політичний конкурент, який відкрив привабливі умови служби та культурної інтеграції для шляхти московського походження. Так, у 1561 р. стався перехід на польсько-литовську службу князя Д. Вишневецького та п’ятигорських князів [5, с. 7-8]. У 1564 р. стався 
перехід на сторону поляків князя А.М. Курбського. Перебуваючи в еміграції, Курбський видав низку викривальних творів, спрямованих на дискредитацію царя [17, с. 66].

Життя Курбського було пов'язане з боями й походами. Проведення військових і верстальних оглядів було звичайним обов'язком воєвод та не свідчило про значну роль Курбського в управлінні державою, а тим більше у проведенні курсу реформ Обраної ради, оскільки він не був їі членом. Крім того, немає жодного свідоцтва про його участь у засіданні Боярської думи. Таким чином, думка про значну роль Курбського у внутрішньополітичному житті країни 1550-х - початку 1560-х рр. базується тільки на його власних заявах [13, с. 85$]$.

На початку 1564 р. Курбський отримав із Литви два листи (від Сигізмунда II та від Радзивілла й Е. Воловича), що гарантували втікачеві підтримку, теплий прийом і нагороду. Таким чином, твердження Курбського про несподіваність його втечі з Московської держави через побоювання несправедливих гонінь $є$ неправдивим [13, с. 87].

Опричнина була пов'язана з потрясіннями Російсько-Литовської війни та з першими важкими поразками царських військ. Це був репресивний захід, спрямований у момент його проведення проти родів людей служивих, заплямованих поразкою у війні, помилками командування, повільністю у військовій службі, небажанням воювати [5, с. 28].

Опричний терор із самого початку був спрямований не лише проти місцевої фронди, а й проти «вторинної фронди» - опозиційно або просто занадто незалежно («шляхетно») налагоджених людей служивих, які чинять опір жорсткій військовій дисципліні, насаджуваній царською владою. Дрібні військовики, які занепадали, становили основу емігрантів, що спрямовувалися за кордон [1, с. 120].

Загроза $з$ півдня - 3 боку Криму й Туреччини - примушувала Московську державу постійно воювати на два фронти. Це виснажувало російські сили, перенапружувало країну. У другій половині XVI століття військова небезпека 3 півдня посилилася.

Варто зазначити, що, приєднуючи Поволжя та Приуралля, російський уряд не переслідував цілі отримання яких-небудь значних економічних вигод. Навпаки, освоєння приєднаних територій вимагало величезних матеріальних і людських ресурсів. В умовах важкої Лівонської війни Московська держава вимушена була тримати в неспокійному Поволжі численні гарнізони, будувати фортеці та регулярно субсидувати місцеву знать, тому головні причини приєднання Середнього Поволжя та Приуралля до Московської держави були пов'язані із зовнішньою політикою країни. На початку XVI століття Московське князівство стало єдиною сильною державою. Татарські ханства та орди, які граничили з нею, хоч і були неспокійними сусідами, проте все-таки кожне окремо небезпеки для Москви не представляли. Вони повинні були визнати російський протекторат або домагатися заступництва найсильнішої євроазіатської мусульманської держави - Туреччини - і її васала - Кримського ханства [2, с. 65].

Саме загроза утворення антиросійського мусульманського союзу ставила основним завданням у східній політиці Москви вирішення питання про державну безпеку. 3 огляду на свої стратегічні інтереси Москва поставила як мету приєднання Поволжя та Приуралля з опертям на військову силу [2, с. 67].

Після обрання Стефана Баторія на польський престол у 1576 р., що припинило внутрішню розправу й негаразди в Польщі, надії на приєднання Лівонії до Московської держави мали значно ослабнути. При цьому російським військам не вдалося взяти Ревель у 1577 р., що значно підбадьорило ворога. Повстали навіть естонські селяни [7, с. 76-77].

До кінця правління Івана IV більша частина центральних районів Московської держави була спустошена, оскільки селяни тікали від руйнівних податків і трудових зобов'язань у пошуку кращих умов на монастирських землях та відкритих кордонах. Уряд намагався піклуватися насамперед про благополуччя людей служивих, тобто дворян. 31581 р. розпочинається перепис населення з метою навести лад у його державному оподаткуванні. У районах, де проводився перепис, селянам тимчасово, упродовж «заповідних років», заборонялося йти від панів. Так створювалися умови для відміни селянського виходу й остаточного затвердження кріпацтва. Проте втеча селян і холопів тривала. Таким чином, у результаті неконтрольованої московським урядом міграції російського населення на південні кордони країни були створені передумови для виникнення громадянської війни на початку XVII століття $[6$, c. 145].

3 XV й аж до кінця XVII століття відбувалася дуже напружена боротьба за представників стану військовиків між польсько-литовською унією та Московською державою. Сама московська система кріпацтва виникала як частина спроб царя спокусити людей служивих залишатися у країні шляхом дарування їм необмеженого контролю над населенням їхніх маєтків. При цьому дворянські роди несли колективну відповідальність за будь-якого їх члена, який покинув службу та країну без дозволу $[10$, c. $28-29]$. 
Висновки. У XVI столітті основним напрямом зовнішньої політики Московської держави був західний, за якого російський уряд прагнув возз'єднати західноросійські землі та проводив експансію у Прибалтиці. Натомість на півдні й сході Москва вела оборонні війни. Невдача на основному зовнішньополітичному напрямі (поразка в Лівонській війні) і значний успіх на другорядному (завоювання Казанського, Астраханського та Сибірського ханств) були зумовлені неспівмірністю протидії, з якою зіткнулася Московська держава. Якщо на заході росіяни повинні були воювати 3 потужним союзом Литви, Польщі, Лівонії та Швеції, які мали у своєму розпорядженні сильні армії, то на сході Москві протистояли відносно слабкі державні системи [2, с. 68].

\section{Література:}

1. Альшиц Д.Н. Начало самодержавия в России. Государство Ивана Грозного. Ленинград : Наука, 1988. 246 с.

2. Бахтин А.Г. Причины присоединения Поволжья и Приуралья к России. Вопросы истории. 2001. № 5. С. $52-72$.

3. Вернадский Г.В. Московское царство. Москва : Ломоносов, 2017. 456 с.

4. Вернадский Г.В. Россия в средние века / пер. с англ. Е.П. Беренштейна, Б.Л. Губмана, О.В. Строгановой. Тверь : ЛЕАН ; Москва : АГРАФ, 2001. 352 с.

5. Ерусалимский К. Московско-литовская война 1562-1566 гг. и введение опричнины: проблемы демографии и земельной политики. Российская история. 2017. № 1. С. 3-31.

6. Зимин А.А., Хорошкевич А.Л. Россия времени Ивана Грозного. Москва : Наука, 1982. 184 с.

7. Иоанн Грозный. Хмельницкий. Потемкин. Суворов. Скобелев / сост. «ЛИО Редактор». Санкт-Петербург : «ЛИО Редактор» и др., 1998. 560 с.

8. История Европы : в 5 т. Москва : Наука, 1993. Т. 3 : От средневековья к новому времени (конец XV - первая половина XVII в.). $656 \mathrm{c.}$

9. Лависс Э. Очерки по истории Пруссии. Пер. с фр. 3-е изд., стереотип. Москва : Едиториал УРСС, 2003.328 с.

10. Лор Э. Российское гражданство: от империи к Советскому Союзу / пер. с англ. М. Семиколенных. Москва : Новое литературное обозрение, 2017. 344 с.

11. Рамбо А. История древней и новой России. Смоленск : Русич, 2001. 640 с.

12. Слонимский Л.З. Основные вопросы политики. Москва : Книга по требованию, 2020. 399 с.

13. Филюшкин А.И. Андрей Михайлович Курбский. Вопросы истории. 1999. № 1. С. 82-96.

14. Халецки О. История Центральной Европы с древних времен до ХХ века. Кипящий котел народов и религий на территории между Германией и Россией / пер. с англ. Л.А. Карповой. Москва : Центрполиграф, 2019. 543 с.

15. Хинце О. Гогенцоллерны. Начало: от первых Цоллернов до Тридцатилетней войны. Санкт-Петербург : Евразия, 2020. $160 \mathrm{c}$.

16. Хорошкевич А.Л. Москва XVI столетия. Отечественная история. 1996. № 4. С. 3-16.

17. Хоскинг Дж. Россия: народ и империя (1552-1917) / пер. с англ. С.Н. Самуйлова. Смоленск : Русич, 2001. 512 с.

18. Черникова Т.В. Россия в период Ливонской войны: предпосылки и возможности вхождения в Европу. Новая и новейшая история. 2014. № 2. С. 125-143. 